\title{
Effect of Screen House on Disease Severity and Coat Protein Diversity of Begomovirus-infected Capsicum frutescens $\mathrm{L}$. 'Cempluk' from Indonesia
}

\author{
Aprilia Sufi Subiastuti, Anggun Cinditya Putri, Cindy Gresyllia Permadani and \\ Budi Setiadi Daryono* \\ Department of Tropical Biology, Faculty of Biology, Gadjah Mada University, Teknika Selatan Street, \\ Sekip Utara, Sleman 55281, Yogyakarta, Indonesia
}

\begin{abstract}
Chili can be infected by Begomovirus through whiteflies (Bemisia tabaci) serving as a vector insect. Begomovirus infection causes dwarf plants and yellow curly leaves. The molecular detection of Begomovirus coat protein gene may serve as a preliminary identification of Begomovirus. This study was conducted to observe the differences in the symptom severity of Begomovirus infection in chilies (Capsicum frutescens L. 'Cempluk') planted inside and outside a screen house. This study also observed whether or not using a screen house in chili farming affects the diversity of the coat protein of Begomovirus. Symptom observation and sampling were conducted in Madurejo, Prambanan, Sleman. Molecular detection was performed by amplifying the coat protein (CP) gene using the universal primer Krusty and Homer. Results showed 7 plant samples with DNA bands \pm 550 bp and confirmed that the plants were positively infected with Begomovirus. The amplified bands were purified and sequenced. The nucleotide sequences were analyzed using BLASTn, followed by phylogenetic analysis using MEGA. Planting chili in the screen house resulted in low disease severity and good crop conditions. The coat protein sequence showed different strains of Begomovirus infected the chili

ARTICLE INFO

Article history:

Received: 29 May 2020

Accepted: 25 August 2020

Published: 28 May 2021

DOI: https://doi.org/10.47836/pjtas.44.2.11

E-mail addresses:

apriliasufi@ugm.ac.id (Aprilia Sufi Subiastuti)

anggun.cinditya.p@mail.ugm.ac.id (Anggun Cinditya Putri) cindy.gresyllia.p@mail.ugm.ac.id (Cindy Gresyllia Permadani)

bs_daryono@mail.ugm.ac.id (Budi Setiadi Daryono)

* Corresponding author plants inside and outside the screen house. Pepper yellow leaf curl Indonesia virus (PepYLCIV) was found inside the screen house while PepYLCIV [Ageratum] was dominant outside the screen house. Both strains are closely related to other Pepper yellow leaf curl virus (PepYLCV) from various regions in Indonesia. Optical
\end{abstract}


manipulation using an ultraviolet screen or screen house was effective in reducing Begomovirus infection and improving plant performance.

Keywords: Begomovirus, coat protein, disease severity, Pepper yellow leaf curl Indonesia virus, plant defense mechanism, plant hormones

\section{INTRODUCTION}

Yellow leaf curling caused by Begomovirus in chili has long been a problem in Indonesia and has caused crop failure in various regions. Yellow leaf curling in chili was first reported in 1999 in West Java as being caused by geminiviruses, mainly from the genus Begomovirus (Rusli et al., 1999). Since 2000, this disease has spread in Yogyakarta and Central Java and has reduced chili production (Sulandari et al., 2006).

Begomovirus-infected chilies are characterized by the presence of specific yellow mosaics on the leaves, curling of leaves from the edges, and stunted plant growth (Sulandari et al., 2006). Begomovirus infections are usually transmitted by whitefly (Bemisia tabaci), which is a viruliferous insect that feeds on plant phloem by injecting enzymes and secreting sap. It reduces plant strength or, in the case of severe attacks, kills the host (Horowitz et al., 2011; Kumar et al., 2017). The whitefly population increases in high humidity and causes crop failure. Begomovirus infection in chili plants may reduce harvest by $20 \%-100 \%$ (Setiawati et al., 2005).
Begomovirus is the largest genus in the Geminiviridae family. It infects a wide range of hosts, such as cultivated plants, weeds around plants, monocotyledonous plants, and dicotyledonous plants in tropical or temperate climates. Some of its strains that were reported to have infected chili and tomato plants were the Tomato leaf curl Java virus (Kon et al., 2006), Pepper yellow leaf curl Indonesia virus, Tomato leaf curl Philippine virus (Sakamto et al., 2005), Ageratum yellow vein virus (Tsai et al., 2009), and Tomato yellow leaf curl Kanchaburi virus (Kenyon et al., 2014). Its genome consists of ssDNA components DNA-A and DNA-B, and each genome size measures 2.5-2.8 kb (Snehi et al., 2011). Begomovirus is divided into two groups according to complete nucleotide sequences: bipartite and monopartite. The bipartite group has two types of ssDNA components, namely, DNA-A and DNA-B; the monopartite group has one circular homologous genomic DNA with DNA-A. Open reading frames (ORFs) in DNA-A and DNA-B in Begomovirus genomes produce several types of proteins with different functions. One of the most important ORFs is AV1/CP. This gene is responsible for expressing the protein coat that forms viral capsids. Furthermore, the $\mathrm{CP}$ gene regulates the transmission of the virus to whiteflies and host plants. The CP gene is the most conserved genome region among all genes/ORFs (Snehi et al., 2011; Wartig et al., 1997). 
Begomoviruses tend to rejoin, thus causing new Begomovirus strains and new plant diseases in various host plants (Chakraborty et al., 2003; Varma \& Malathi, 2003). Therefore, the detection of Begomovirus particles is needed to determine infected plants and find the source of infection. The assessment of viral diseases can be conducted by morphological observation and molecular detection. Symptom monitoring is a simple, fast, and inexpensive method for assessing the presence of Begomovirus infection. However, the results often vary due to subjective interpretations and effects of environmental conditions, hence the need to conduct reliable assessments, such as molecular detection (González-Pérez et al., 2011). The application of polymerase chain reaction (PCR) techniques to detect viral infections in plants is a sensitive, reliable, reproducible, and effective method, especially for large samples (Lopez et al., 2008). Previous studies reported the use of molecular methods to detect Begomovirus infections in chilies and eggplants (Maruthi et al., 2007), okra (Venkataravanappa et al., 2018), and tomatoes (Kusumaningrum et al., 2015). The present study was conducted to determine the effect of using screen houses in chili (Capsicum frutescens L. 'Cempluk') cultivation on the severity of Begomovirus infection and the diversity of Begomovirus coat proteins that cause yellow leaf curling in chilies using molecular methods.

\section{METHODS}

\section{Morphological Observation and Sample Collection}

Observation and sampling were performed in Madurejo, Sleman, Yogyakarta. Symptom observations were carried out in two study areas, namely, outside and inside a screen house in February-October 2018. A total of 469 and 41 chili plants (Capsicum frutescens L. 'Cempluk') were planted outside and inside the screen house. Virus infection in chili was classified into six scale groups on the basis of the plant height and scale of virus infection established by Srivastava et al. (2017) with a few modifications. The scale was as follows: 0: healthy plants, scale 1: yellow spot leaves, scale 2: yellow spots and moderately curved leaves, scale 3: yellow spots and curved leaves, scale 4: yellow and curly leaves, scale 5: fully yellow and curly leaves, stunted plants. Disease incidence (DI) was calculated using the following formula (Srivastava et al., 2017):

$$
D I=\frac{\text { Number of infected plants }}{\text { Total plants }} \times 100 \%
$$

The scoring results were then converted into the disease severity (DS) index using the following formula to reveal DS (S. Islam et al.., 2010):

$$
D S=\frac{\sum(n i \times V i)}{Z \times N} \times 100 \%
$$

where, $n_{i}=$ sum of plant in each score, $V_{i}$ $=$ score of symptoms, $\mathrm{Z}=$ value of highest 
symptom, and $\mathrm{N}=$ total number of observed plants.

\section{DNA Isolation and Amplification of Coat Protein Gene}

DNA was extracted from chili leaf samples by using the commercial plant DNA extraction kit Illustra Phytopure ${ }^{\mathrm{TM}}$ and by following the processes described by Daryono and Natsuaki (2002) with slight modification. Furthermore, DNA was checked quantitatively using NanoDrop $^{\text {TM }}$ spectrophotometry with $\lambda$ 260/280 $\mathrm{nm}$. Universal primers for Begomovirus coat protein, namely, Krusty and Homer (Krusty [Forward]: 5'CCNMRDGGHTGTGARGGNCC'3; $\mathrm{H}$ o m e r [ $\mathrm{R}$ e $\mathrm{v}$ e $\mathrm{r}$ s e ] : 5'SVDGCRTGVGTRCANGCCAT'3), were utilized to amplify the partial coat protein of Begomovirus by using the PCR thermal cycler (Revill et al., 2003). Infected plants show a DNA band at about $\sim 550$ bp in electrophoresis visualization. A PCR mix $(25 \mu \mathrm{L})$ containing $12.5 \mu \mathrm{L}$ PCR kit Bioline 2x MyTaq ${ }^{\mathrm{TM}}$ HS RedMix (Bioline, United Kingdom), $1.5 \mu \mathrm{L}$ for each primer (10 pmol), $1.5 \mu \mathrm{L}$ DNA samples (100 pmol), $0.5 \mu \mathrm{L}$ $\mathrm{MgCl}_{2}$, and $7.5 \mu \mathrm{L}$ distilled water was used. The PCR reaction was started with initial denaturation at $95^{\circ} \mathrm{C}$ for $5 \mathrm{~min}$; continued with 35 cycles of $95^{\circ} \mathrm{C}$ for $30 \mathrm{~s}, 55^{\circ} \mathrm{C}$ for 30 $\mathrm{s}$, and $72^{\circ} \mathrm{C}$ for $45 \mathrm{~s}$; and then followed by a final extension at $72^{\circ} \mathrm{C}$ for $5 \mathrm{~min}$. The PCR results were analyzed using $2 \%$ of agarose gel, which was stained with FloroSafe DNA stain (First BASE, Singapore).

\section{DNA Sequence Analysis}

Positive PCR samples were sent to First BASE, Singapore for sequencing. Then, nucleotide sequences were assembled using GeneStudio ${ }^{\mathrm{TM}}$ software, followed by BLASTn analysis for comparing sequences with other coat protein gene sequences of Begomovirus in GenBank. A phylogenetic tree was constructed using MEGA 7.0 with 2,000 bootstraps and then edited manually.

\section{RESULTS}

\section{Observed Symptoms on Leaves}

The symptom observation of Begomovirus infection was focused on leaf morphology. However, some of the plants observed were found to be dead due to wilting rather than the Begomovirus infection. Seven and nine dead plants were found inside and outside the screen house, respectively. The differences in the responses of the plants inside and outside the screen house to the Begomovirus infection are detailed in Table 1. The results of the study showed that the incidence and severity of the disease was

Table 1

Response of chili to natural Begomovirus infection

\begin{tabular}{lccc}
\hline & $\begin{array}{c}\text { Symptomatic plants/ total } \\
\text { plants }\end{array}$ & $\begin{array}{c}\text { Disease } \\
\text { incidence (\%) }\end{array}$ & $\begin{array}{c}\text { Disease } \\
\text { severity (DS) }\end{array}$ \\
\hline Chili inside screen house & $25 / 41$ & 60.9 & 42 \\
Chili at field & $455 / 464$ & 97 & 53.8 \\
\hline
\end{tabular}


greater in the chili plants outside the screen house than in those planted inside the screen house. The use of a screen house thereby reduced the Begomovirus infection because it protected the plants from whiteflies while minimizing the effects of environmental stress on plant development.

The severity of the morphological symptoms on the leaves of the chili plants was grouped into six categories according to the observed symptoms (Figure 1). This scale determination was based on the study of Srivastava et al. (2017). The most common morphological symptoms in the chilies planted outside the screen house were yellow and curved leaves (scale 3 ). Those observed in the chilies inside the screen house indicated relatively health plants despite the presence of yellow spots on the leaves (scale 1). The real difference was that no plant inside the screen house showed yellow and curly leaves (scale 4).
The most severe symptoms observed in both locations were completely yellow and curly leaves and stunted growth.

\section{Effect of Begomovirus Infection on Plant Height}

One symptom of Begomovirus infection is stunted plant growth. Hence, plant height measurements were carried out on the plants in both study areas. The chilies planted outside the screen house were measured to be about 126-135 cm tall, whereas those planted in the screen house were taller with a height of 142-149 cm. Rank analysis in SPSS ${ }^{\circ}$ software also showed a significant difference in the average heights of the chili plants outside and inside the screen house (Table 2). This condition supports the previous explanation that planting chilies in a screen house provides good plant conditions.

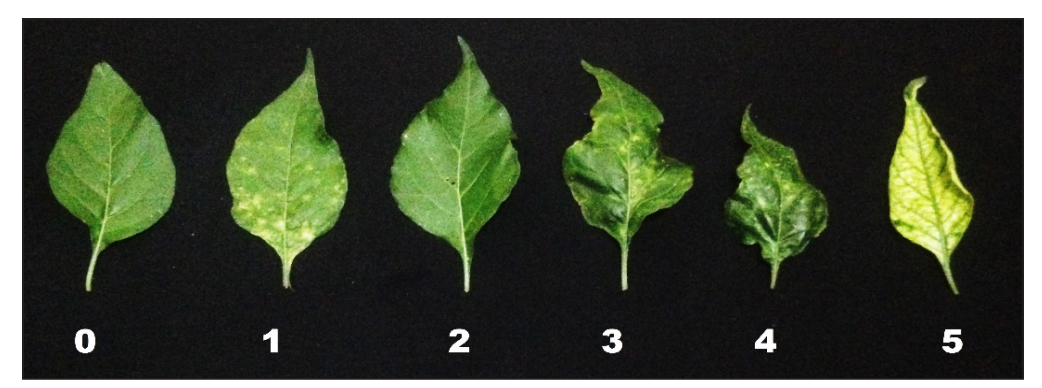

Figure 1. Morphological comparison of leaves based on the scale of virus infection: 0: healthy plants, 1: yellow spot leaves, 2: yellow spots and moderately curved leaves, 3: yellow spots and curved leaves, 4: yellow and curly leaves, 5: yellow and curly leaves, stunted plants, respectively

Table 2

Differences in average plant heights of chilies planted inside and outside the screen house

\begin{tabular}{ccccc}
\hline & Location & N & Mean rank & Sum of rank \\
\hline Plant height & Screen house & 34 & 303 & 10302 \\
& Field & 469 & 248.3 & 116454 \\
& Total & 503 & & \\
\hline
\end{tabular}




\section{Molecular Diagnosis of Begomovirus Infection}

Total DNA was extracted from 16 plant samples in the six infection scale groups; that is, eight samples were obtained from each of the two locations. A set of primers (Krusty and Homer) was used to amplify the CP gene region using the PCR technique. However, only 7 samples from the 16 samples were amplified; these samples showed a target DNA band at $\pm 550 \mathrm{bp}$ and were positively infected by Begomovirus (Figure 2). A total of five samples from outside the screen house produced the targeted bands, whereas only two samples from inside the screen house did. Begomovirus DNA was only found in the samples in the 3-5 scale; none was found in those in the $0-2$ scale. This result indicated that the severity of the symptoms was correlated with the concentration of virus particles. The low severity of symptoms indicated low viral DNA concentrations and vice versa.

\section{Diversity of Coat Protein Sequences}

Each of the two samples from each location was sequenced to analyze the CP gene sequence. Then, the obtained sequences were analyzed using BLASTn to compare them with other nucleotide sequences in GenBank as the initial identification of Begomovirus strains. Table 3 shows that the two locations have the potential to be infected by the Pepper yellow leaf curl Indonesia virus with a CP percentage of similarity of $>97 \%$. According to the CP sequences, the samples from the screen house showed a close genetic relationship

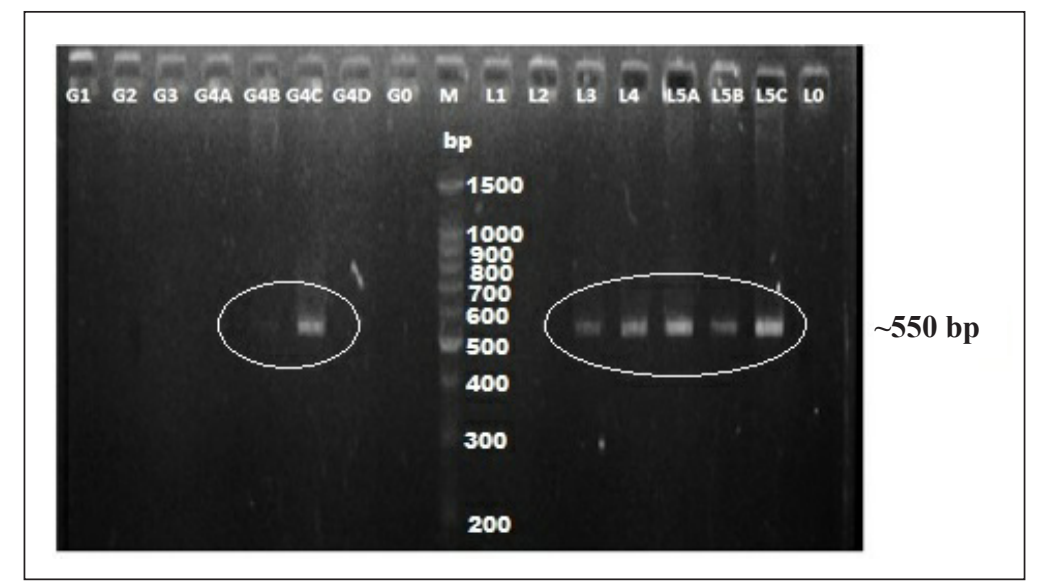

Figure 2. Electrophoresis visualization of CP gene amplification

Note. G: inside screen house samples; L: outside screen house samples; 0-6: infection scale

Table 3

Sequence analysis of Begomovirus CP gene

\begin{tabular}{lccc}
\hline \multicolumn{1}{c}{ Sample } & \% Identity & Potential Begomovirus species & GenBank accession \\
\hline Inside screen house & 99.52 & PepYLCIV & AB267834 \\
Outside screen house & 97.12 & PepYLCIV [Ageratum] & AB267838 \\
\hline
\end{tabular}


with the Pepper yellow leaf curl Indonesia virus, whereas the samples from outside the screen house showed CP sequences with $97.12 \%$ similarity to the Pepper yellow leaf curl Indonesia virus [Ageratum]. However, this analysis cannot be used for final identification as it may only serve as an indication of the prevalence of Begomovirus strains that cause curly leaves in chili 'Cempluk' planted inside and outside a screen house.

The nucleotide sequence of the CP gene from each location was compared with 22 nucleotide sequences from different virus strains to evaluate their genetic relationship.
The genome samples used in the comparison came from several plants, such as Capsicum frutescens/chili, Capsicum annum, Solanum lycopersicum/tomato, and Ageratum (weeds). The analysis was performed by constructing a phylogenetic tree in MEGA 7.0. The phylogenetic tree showed that the two samples from the two locations are closely related to PepYLCIV isolated from various regions in Indonesia, such as West Sumatra, Banda Aceh, and Bogor (Figure 3). Begomoviruses detected in the plants from the inside and outside of the screen house were grouped into different clades. The samples isolated from inside the screen

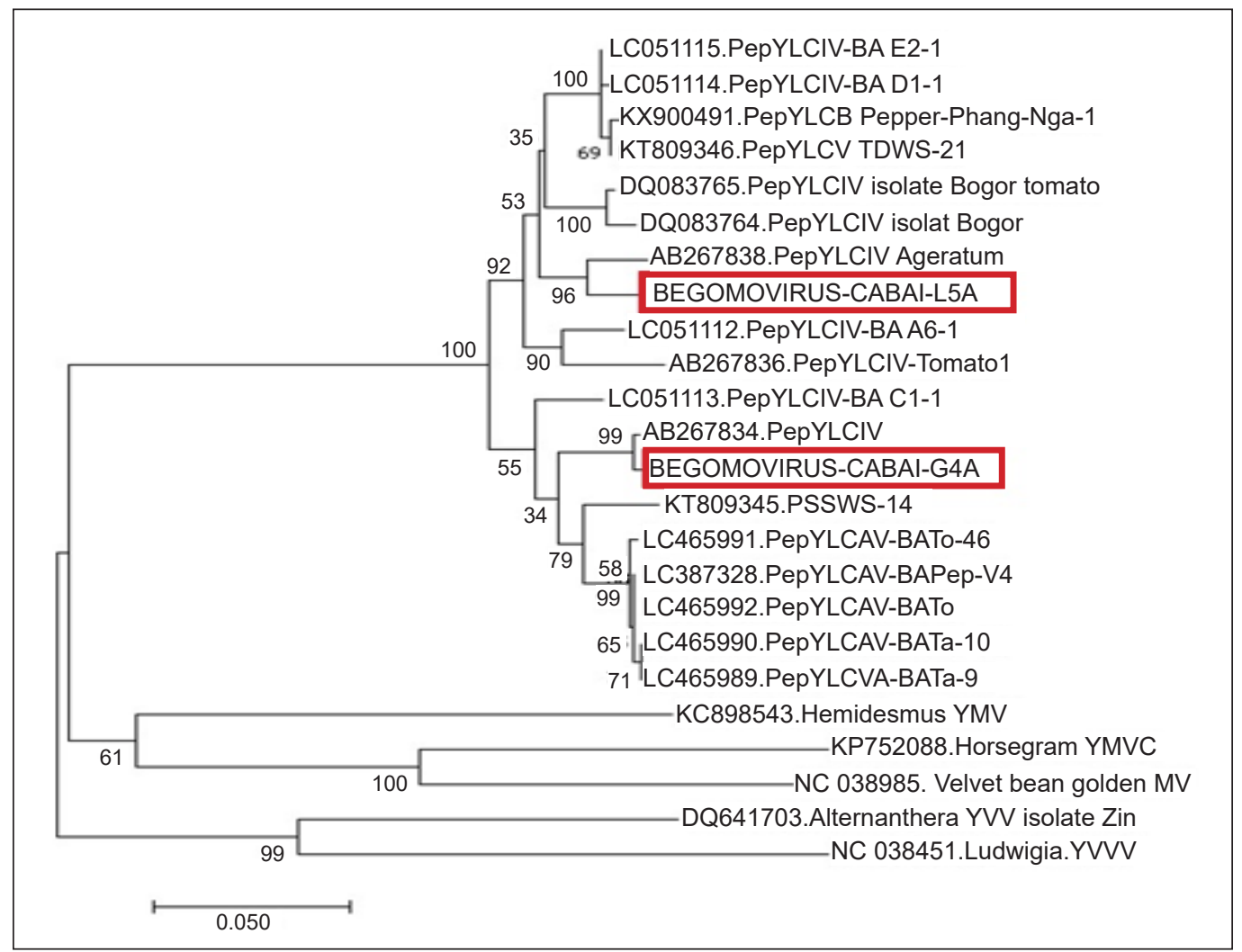

Figure 3. Phylogenetic tree of the partial CP gene of Begomovirus constructed using the neighbor joining algorithm with 2,000 bootstraps 
house showed a close genetic relationship with PepYLCIV isolated from Bogor, West Java. The samples from outside the screen house showed a close genetic relationship with PepYLCIV [Ageratum] (Figure 3). These results indirectly indicated that the source of the Begomovirus infection outside the screen house came from nearby plantation crops or infected weeds.

\section{DISCUSSION}

Begomovirus infection in chili is a serious problem in Indonesian agriculture. Chili is one of the horticultural commodities with high economic value. Chili plants show several obvious symptoms when infected with Begomovirus; these symptoms include yellow spots on the leaf surface, vein clearing, thickening at the leaf bones, and cupping (Sulandari et al., 2006). Morphological observation is a simple way to identify the early symptoms of Begomovirus infection (González-Pérez et al., 2011). The results of symptom observations are usually converted into DI and DS to obtain a reliable estimation for plant response determination (Bock et al., 2015). The present study showed that DS inside the screen house was lower than that outside the screen house (Table 1). This result might be due to the fact that the condition of the plants in the screen house was more controlled than that outside the screen house. Inside the screen house, the plants were not exposed to abiotic stress, such as high temperatures, rain, and extreme temperature changes. This condition can affect plant resistance to Begomovirus infection. Simultaneous abiotic and biotic stresses can exert antagonistic, synergistic, or additive effects on plants, and these effects may lead to increased or decreased susceptibility to stresses. The great damage in the field with uncontrolled conditions can be attributed to secondary stress from a combination of two stressors exerting a negative or additive effect on plants (Asselbergh et al., 2008). Suleman et al. (2001) reported that drought stress in common beans infected with Macrophomina phaseolina leads to other symptoms. The same result was found when exogenous ABA was applied to detached tomato leaves; such application increases the susceptibility of wild type plants to Botrytis cinerea (Audenaert et al., 2002).

The results of the current study also showed that planting in the screen house led to a reduction in the population of whiteflies. Such outcome was deduced as the cause of the reduction in Begomovirus infection because this virus is only transmitted by whiteflies. This result was also reflected in the low scale of yellow leaf curling symptoms found in the plants in the screen house. Meanwhile, the plants outside the screen house showed diverse symptoms. This result may be due to the uncontrolled growth of whitefly infestation because Begomovirus can be carried by whitefly infestation from nearby weeds or crops that have been infected previously. Some wild plants (Hyptis brevipes, Physalis floridana, and Crotalaria juncea) and weeds (Ageratum conyzoides) are often found 
around chili fields, and they are susceptible to Begomovirus infections (Sulandari et al., 2006).

As Begomovirus cannot be restrained directly, the most effective strategies are controlling the population of Bemisia tabaci. Whitefly, from the family Aleyrodidae and the Homoptera order, is a complex cryptic species of small insects with a piercing and sucking mouth type. These insects are distributed globally in tropical, subtropical, and low-climate regions (Wang et al., 2018). When infecting plants, whiteflies cause the shrinkage of plant nutrients as they spread the virus. Through their stylet, whiteflies suck the phloem liquid, thereby decreasing and even draining the nutrients in the leaves completely and causing the leaves to turn yellow. The reduction of leaf nutrition also causes a slope in plant photosynthesis activity while weakening the plants (Horowitz et al., 2011). Whitefly infestations affect plants in three stages of growth: nursery, flowering, and fruiting. Whiteflies in the nymph and imago stages suck the juice of plants through their mouth resting in a protected position in the rostrum. Whiteflies infect intercellular plant tissues and introduce fluid into the phloem, thereby inhibiting photosynthesis and affecting fruit conditions (Mohamed, 2012). Chemical control is not highly effective in preventing infestations because virus acquisition, as well as the development of virus resistance, requires a short time. Previous studies revealed the effects of insecticides on whiteflies after virus acquisition (Antignus, 2010).
However, after a certain period of time, the effectiveness of insecticides decreases due to adaptations that cause resistance to insecticides; moreover, the relatively high toxicity of these insecticides for nontarget organisms (including arthropods and humans) makes them ineffective in the efforts to control whitefly infestations (Mascarin et al., 2013; Wang et al., 2018).

Whiteflies only rely on their vision for navigation and orientation because their olfactory reaction is poor. They are sensitive to ultraviolet (UV) and the visible range of the electromagnetic spectrum. Numerous studies also reported that a disruption in UV vision might cause a disturbance in dispersal or orientation (Antignus, 2010). The screen of a screen house eliminates UV spectrum between 280 and $380 \mathrm{~nm}$, thereby significantly diminishing the infestation of insects (including thrips, aphids, and whiteflies) on crop plants. The use of a screen has also been reported to reduce Tomato yellow leaf curl virus and Cucumber yellowing stunting disorder virus infections in tomato and cucumber (Kumar \& Phoeling, 2006). Thus, using a screen house could hinder the entrance of whiteflies, which disrupt plant development. Although whiteflies were still found inside the screen house in the current study, they were fewer than those found outside the screen house.

Dramatic morphological and physiological changes in virus-infected plants result in the reduction of crop yield. Many previous reports revealed that virus infections can disrupt metabolic and 
physiological processes, such as respiration, transpiration, and photosynthesis (Tajul et al., 2011). The results of the current study are in agreement with those of Khalil et al. (2014), who reported that Begomovirus infections in tomato cause the reduction of root length, number of plant leaves, shoot height, and the fresh and dry weight of shoots and roots of plants. The decrease in morphological quality and quantity might be related to the reduction of photosynthesis level due to the disruption of photosynthesis pigments. Begomovirus infections have been reported to cause mineral deficiency that increases the degradation/damage of the chloroplast thylakoid membrane (Khalil et al., 2014). Radwan et al. (2007) also revealed that Zucchini yellow mosaic virus-infected plants present decreased chlorophyll pigments. The disruption of chlorophyll pigments may be related to the production of plant defense hormones, such as salicylic acid (SA) and jasmonic acid (JA). JA and SA elicit the expressions of specific hormone-responsive genes that restrict invading pathogens (Spoel et al., 2007). Meanwhile, chloroplasts also play a role in innate immunity by restricting viral spread and systemic infections; they also serve as the site for defense hormone production. Chloroplasts undergo structural and functional damage as they become the main target of virus infections (Bhattacharyya \& Chakraborty, 2018).

In the current work, the molecular detection of Begomovirus was conducted using coat protein genes. The coat protein gene sequence can be used to detect the presence of Begomovirus infection quickly and accurately with molecular characterization. CP gene sequences have conserved areas near the 5' and 3' ends and varied regions at the $5^{\prime}$ end along 200 nucleotides (Sinha et al., 2013). Thus, mutations in CP are associated with the emergence of Begomovirus variations (Subiastuti et al., 2019). Moreover, this sequencing has been used for the early identification of begomoviruses associated with cultivation plants in Mexico. However, the sequencing of the full DNA-A of Begomovirus needs to be carried out to achieve precise and accurate identification results (Hernandez-Zepeda et al., 2007). Previous studies also used this method for the quick identification of Begomovirus in melon (Subiastuti et al., 2019), tobacco (Widarta et al., 2017), tomato (Kusumaningrum et al., 2015), bitter melon (Tiwari et al., 2010), and mung bean (M. N. Islam et al., 2012).

Sample L5A was planted outside the screen house. Wild plants and weeds, as well as overlapping planting systems, were found near this study location. This condition facilitates the great prevalence of mixed infections (Subiastuti et al., 2019). The result herein also indicates that the sources of Begomovirus infection are nearby plantation crops or weeds that have been infected. Ageratum is one of the most common weeds found in fields near plantation crops, and they might be the source of the Begomovirus infection in this study. This phenomenon is in agreement with the results obtained by Shibuya et al. (2007) and Sakata et al. (2008), who found 
that the Indonesia yellow vein disease in Ageratum conyzoides plants is caused by PepYLCIV. As reported by Mubin et al. (2009), weeds are reservoirs of Begomovirus that may be responsible for viral infections in crop plants. Weeds also facilitate virus recombination as they frequently harbor multiple viruses; this process results in new viruses/new strains. Various studies also reported Begomovirus infection in weeds. Graham et al. (2007) found that weeds of the genus Sida persistently harbored several begomoviruses originating from pseudorecombination or molecular recombination; this finding led to the identification of Sida micrantha mosaic virus. Moreover, Deinbollia mosaic virus, a weed-infecting Begomovirus, has been reported to infect Solanaceae and Euphorbiaceae (Kyallo et al., 2017).

The L5 samples in the current work showed possible differences in PepYLCIV strains that infected the chili plants outside the screen house. This difference might be due to the condition of the plants in the screen house being more homogeneous than that outside the screen house. Further research is needed to obtain a full sequencing of the viral genome to complete the identification of the differences in the Begomovirus strains in the plants inside and outside the screen house and to determine potential polymorphism in both strains associated with DI or DS. The presence or absence of betasatellite and differences in DNA-A sequences might influence the severity of the disease in plants and host determination (Mansoor et al., 2003; Zubair et al., 2017).

\section{CONCLUSION}

Optical manipulation using a UV screen or a screen house was effective in reducing either Begomovirus infection or whitefly population. Understanding the source of infection will help to prevent the spread of infection. Molecular detection offers a fast method to detect the source of Begomovirus infection accurately while detecting its diversity. These strategies are expected to be a sustainable agriculture effort as they may reduce the use of insecticides and serve as alternatives to the development of resistant cultivars for controlling Begomovirus infections.

\section{ACKNOWLEDGMENTS}

This research work was supported by the Final Project Recognition (RTA) program 2019 (2129/UN1/DITLIT/DIT-LITLT/2019) of Universitas Gadjah Mada.

\section{REFERENCES}

Antignus, Y. (2010). Optical manipulation for control of Bemisia tabaci and its vectored viruses in the greenhouse and open field. In P. A. Stansly \& S. E. Naranjo (Eds.), Bemisia: Bionomics and management of a global pest (pp. 349-356). Springer. https://doi.org/10.1007/978-90-4812460-2 13

Asselbergh, B., Achuo, A. E., Hofte, M., \& van Gijegem, F. (2008). Abscisic acid deficiency leads to rapid activation of tomato defence responses upon infection with Erwinia chrysanthemi. Molecular Plant Pathology, 9(1), 11-24. https:// doi.org/10.1111/j.1364-3703.2007.00437.x

Audenaert, K., de Meyer, G. B., \& Hofte, M. (2002). Abscisic acid determines basal susceptibility of tomato to Botrytis cinerea and suppresses 
salicylic acid-dependent signaling mechanisms. Plant Physiology, 128(2), 491-501. https://doi. org/10.1104/pp.010605

Bhattacharyya, D., \& Chakraborty, S. (2018). Chloroplast: The Trojan horse in plant-virus interaction. Molecular Plant Pathology, 19(2), 504-518. https://doi.org/10.1111/mpp.12533

Bock, C. H., El Jarroudi, M., Kouadio, L. A., Mackles, C., Chiang, K. S., \& Delfosse, P. (2015). Disease severity estimates - Effects of rater accuracy and assessment methods for comparing treatments. Plant Disease, 99(8), 1104-1122. https://doi. org/10.1094/PDIS-09-14-0925-RE

Chakraborty, S., Pandel, P. K., Banerjee, M. K., Kallo, G., \& Fauquet, C. M. (2003). Tomato leaf curl Gujarat virus, a new Begomovirus species causing a severe leaf curl disease of tomato in Vanarisi, India. Phytopathology, 93(12), 1485-1494. https://doi.org/10.1094/ PHYTO.2003.93.12.1485

Daryono, B. S., \& Natsuaki, K. T. (2002). Application of random amplified DNA markers for detection of resistant cultivars of melon (Cucumis melo L.) against cucurbit virus. Acta Horticulturae, 588, 321-329. https://doi.org/10.17660/ ActaHortic.2002.588.52

González-Pérez, J. L., Espino-Gudiño, M. C., Torres-Pacheco, L., Guevara-González, R. G., Herrera-Ruiz, G., \& Rodríguez-Hernández, V. (2011). Quantification of virus syndrome in chili peppers. African Journal of Biotechnology, 10(27), 5236-5250. https://doi.org/10.5897/ AJB10.1165

Graham, A. P., Stewart, C. S., \& Roye, M. E. (2007). First report of a begomovirus infecting two common weeds: Malvastrum americanum and Sida spinosa in Jamaica. Plant Pathology, 56(2), 340. https://doi.org/10.1111/j.13653059.2007.01527.x

Hernandez-Zepeda, C., Idris, A. M., Carnevali, G., Brown, J. K., \& Moreno-Valenzuela, O.
A. (2007). Preliminary identification and coat protein gene phylogenetic relationships of begomoviruses associated with native flora and cultivated plants from the Yucatan Peninsula of Mexico. Virus Genes, 35(3), 825-833. https://doi. org/10.1007/s11262-007-0149-1_

Horowitz, A. R., Antignus, Y., \& Gerling, D. (2011) Management of Bemisia tabaci whiteflies. In: W. M. O. Thompson (Ed.), The whitefly, Bemisia tabaci (Homoptera: Aleyrodidae) interaction with geminivirus-infected host plants (pp. 293322). Springer. https://doi.org/10.1007/978-94007-1524-0_11

Islam, M. N., Sony, S., \& Borna, R. (2012). Molecular characterization of mungbean yellow mosaic disease and coat protein gene in mungbean varieties of Bangladesh. Plant Tissue Culture Biotechnology, 22(1), 73-81. https://doi.org/10.3329/ptcb. v22i1.11263

Islam, S., Munshi, A. D., Mandal, B., Kumar, R., \& Behera, T. K. (2010). Genetics of resistance in Luffa cylindrica Roem. against Tomato leaf curl New Delhi virus. Euphytica, 174(1), 83-89. https://doi. org/10.1007/s10681-010-0138-7

Kenyon, L., Tsai, W., Shih, S., \& Lee, L. (2014). Emergence and diversity of begomoviruses infecting solanaceous crops in East and Southeast Asia. Virus Research, 18, 104-113. https://doi. org/10.1016/j.virusres.2013.12.026_

Khalil, R. R., Bassiouny, F. M., El-Doundoug, K. A., Abo-Elmaty S., \& Yousef, M. S. (2014). A dramatic physiological and anatomical changes of tomato plants infecting with tomato yellow leaf curl geminivirus. Journal of Agricultural Technology, 10(5), 1213-1229.

Kon, T., Hidayat, S. H., Hase, S., Takahashi, H., \& Ikegami, M. (2006). The natural occurrence of two distinct begomoviruses associated with DNA $\beta$ and a recombinant DNA in a tomato plant 
from Indonesia. Phytopathology, 96(5), 517-525. https://doi.org/10.1094/PHYTO-96-0517

Kumar, P., \& Poehling, H. M. (2006). UV-blocking plastic films and nets influence vectors and virus transmission on screen house tomatoes in the humid tropics. Environmental Entomology, 35(4), 1069-1082. https://doi.org/10.1603/0046225X-35.4.1069

Kumar, V., Palmer, C., McKenzie, C. L., \& Osborne L. S. (2017). Whitefly (Bemisia tabaci) management program for ornamental plants. http://edis.ifas. ufl.edu

Kusumaningrum, F., Hartono, S., Sulandari, S., \& Somowiyarjo, S. (2015). Infeksi ganda Begomovirus dan Crinivirus pada tanaman tomat di Kabupaten Magelang, Jawa Tengah [Begomovirus and Crinivirus double infection in tomato plants in Magelang Regency, Central Java]. Jurnal Perlindungan Tanaman Indonesia, 19(2), 60-64. https://doi.org/10.22146/jpti.17542

Kyallo, M., Ateka, E. M., Seruwagi, P. S., AscencioIbanez, J. S., Ssemakula, M., Skilton, R., \& Ndunguru, J. (2017). Infectivity of Deinbollia mosaic virus, a novel weed-infecting begomovirus in East Africa. Archives of Virology, 162(11), 3439-3445. https://doi.org/10.1007/ s00705-017-3495-x

Lopez, M. M., Llop, P., Olmos, A., Marco-Noales, E., Cambra, M., \& Bertolini, E. (2008). Are molecular tools solving the challenges posed by detection of plant pathogenic bacteria and viruses?. Current Issues Molecular Biology, 11(1), 13-46.

Mansoor, S., Briddon, R. W., Zafar, Y., \& Stanley, J. (2003). Geminivirus disease complexes: An emerging threat. Trends on Plant Science, 8(3), 128-134. https://doi.org/10.1016/S13601385(03)00007-4

Maruthi, M. N., Rekha, A. R., Mirza, S. H., Alam, S. N., \& Colvin, J. (2007). PCR-based detection and partial genome sequencing indicate high genetic diversity in Bangladeshi begomoviruses and their whitefly vector, Bemisia tabaci. Virus Genes, 34(3), 373-385. https://doi.org/10.1007/ s11262-006-0027-2

Mascarin, G. M., Kobori, N. N., Quintela, E. D., \& Delalibera Jr., I. D. (2013). The virulence of entomopathogenic fungi against Bemisia tabaci biotype B (Hemiptera: Aleyrodidae) and their conidial production using solid substrate fermentation. Biological Control, 66(3), 209-218. https://doi.org/10.1016/j.biocontrol.2013.05.001

Mohamed, M. A. (2012). Impact of planting dates, spaces and varieties on infestation of cucumber plants with whitefly, Bemisia tabaci (Genn.). The Journal of Basic and Applied Zoology, 65(1), 1720. https://doi.org/10.1016/j.jobaz.2012.01.003

Mubin, M., Briddon, R. W., \& Mansoor, S. (2009). Diverse and recombinant DNA betasatellites are associated with a begomovirus disease complex of Digera arvensis, a weed host. Virus Research, 142(1-2), 208-212. https://doi.org/10.1016/j. virusres.2009.01.020

Radwan, D. E. M., Fayez, K. A., Mahmoud, S. Y., Hamad, A., \& Lu, G. (2007). Physiological and metabolic changes of Cucurbita pepo leaves in response to Zucchini yellow mosaic virus (ZYMV) infection and salicylic acid treatments. Plant Physiology and Biochemistry, 45(6-7), 480-489. https://doi.org/10.1016/j. plaphy.2007.03.002

Revill, P. A., Ha, C. V., Porchun, S. C., Vu, M. T., \& Dale, J. L. (2003). The complete nucleotide sequence of two distinct geminiviruses infecting cucurbits in Vietnam. Archives of Virology, 148(8), 1523-1541. https://doi.org/10.1007/ s00705-003-0109-6

Rusli, E. S., Hidayat, S. H., Suseno, R., \& Tjahjono, B. (1999). Geminivirus asal cabai: Kisaran inang dan cara penularan [Geminivirus from chili: Range of host and mode of transmission]. Bulletin HPT, 11(1), 126-131. 
Sakamto., Kon, T., Hidayat, S, H., Ito, K., Hase, S., Takahashi, H., \& Ikegami, M. (2005). Begomoviruses associated with leaf curl disease of tomato in Java, Indonesia. Journal of Phytopathology, 153(9), 562-566. https://doi. org/10.1111/j.1439-0434.2005.01020.x

Sakata, J., Shibuya, Y., \& Sharma, P. (2008). Strains of a new bipartite Begomovirus, Pepper yellow leaf curl Indonesia virus, in leaf-curl-diseased tomato and yellow-vein-diseased ageratum in Indonesia. Archives of Virology, 153(12), 2307-2231. https://doi.org/10.1007/s00705-008-0254-z

Setiawati, W., Udiarto, B. K., \& Soetiarso, T. A. (2005). Pengaruh varietas dan sistem tanam cabai merah terhadap penekanan populasi hama kutu kebul [Effect of varieties and planting systems of red chili on the suppression of whitefly populations]. Jurnal Hortikultura, 18(1), 55-61.

Shibuya, Y., Sakata, J., Sukamto, N., Kon, T., Sharma, P., \& Ikegami, M. (2007). First report of Pepper yellow leaf curl Indonesia virus in Ageratum conyzoides in Indonesia. Plant Disease, 91(9), 1198. https://doi.org/10.1094/PDIS-91-9-1198B

Sinha, D. P., Saxena, S., Singh, M., \& Tiwari, S. K. (2013). Phylogenetic relationship of coat protein genomic components of Chili leaf curl virus. Vegetable Science, 40(2), 149-154.

Snehi, S. K., Khan, M. S., Raj, S. K., \& Prasad, V. (2011). Complete nucleotide sequence of Croton yellow vein mosaic virus and DNA- $\beta$ associated with yellow vein mosaic disease of Jatropha gossypifolia in India. Virus Genes, 43, 93-101. https://doi.org/10.1007/s11262-011-0605-9

Spoel, S. H., Johnson, J. S, \& Dong, X. (2007). Regulation of tradeoffs between plant defenses against pathogens with different lifestyles. PNAS, 104(47), 18842-18847. https://doi.org/10.1073/ pnas.0708139104

Srivastava, A., Mangal, M., Saritha, R. K., \& Kalia, P. (2017). Screening of chili (Capsicum spp.) lines for resistance to the begomoviruses causing chilli leaf curl disease in India. Crop Protection, 100, 177-185. https://doi.org/10.1016/j. cropro.2017.06.015

Subiastuti, A. S., Hartono, S., \& Daryono, B. S. (2019). Detection and identification of Begomovirus infecting Cucurbitaceae and Solanaceae in Yogyakarta, Indonesia. Biodiversitas, 20(3), 738744. https://doi.org/10.13057/biodiv/d200318

Sulandari, S., Hidayat, S. H., Suseno, R., Jumanto, H., \& Sosromarsono. (2006). Deteksi dan kajian kisaran inang virus penyebab penyakit daun keriting kuning cabai [Detection and host range study of virus associated with pepper yellow leaf curl disease]. Hayati, 13(1), 1-6. https://doi. org/10.1016/S1978-3019(16)30371-0

Suleman, P., Al-Musallam, A., \& Menezes, C. A. (2001). The effect of solute potential and water stress on black scorch caused by Chalara paradoxa and Chalara radicicola on date palms. Plant Disease, 85(1), 80-83. https://doi. org/10.1094/PDIS.2001.85.1.80

Tajul, M. I., Naher, K., Hossain, T., Siddiqui, Y., \& Sariah, M. (2011). Tomato yellow leaf curl virus (TYLCV) alters the phytochemical constituents in tomato fruits. Australian Journal of Crop Sciences, 5(5), 575-581.

Tiwari, A. K., Sharma, P. K., Khan, M. S., Snehi, S. K., Raj, S. K., \& Rao, G. P. (2010). Molecular detection and identification of Tomato leaf curl New Delhi virus isolate causing yellow mosaic disease in bitter gourd (Momordica charantia), a medicinally important plant in India. Medicinal Plants, 2(2), 117-123. https://doi.org/10.5958 /j.0975-4261.2.2.018

Tsai, W. S., Shih, S. L., Green, S. K., Lee, L. M., Luther, G. C., Ratulangi, M., \& Sembel, D. T. (2009). Identification of a new begomovirus associated with yellow leaf curl diseases of tomato and pepper in Sulawesi, Indonesia. Plant Disease, 93(3), 321. https://doi.org/10.1094/ PDIS-93-3-0321C 
Varma, A., \& Malathi, V. G. (2003). Emerging geminivirus problems: A serious threat to crop production. Annals of Applied Biology, 142(2), 145-146. https://doi. org/10.1111/j.1744-7348.2003.tb00240.x

Venkataravanappa, V., Reddy, C. N. L., Saha, S., \& Reddy, M. K. (2018). Recombinant Tomato leaf curl New Delhi virus is associated with yellow vein mosaic disease of okra in India. Physiol Molecular Plant Pathology, 104, 108-118. https://doi.org/10.1016/j.pmpp.2018.10.004

Wang, R., Wang, J., Che, W., \& Lhuo, C. (2018). First report of field resistance to cyantraniliprole, a new anthranilic diamide insecticide, on Bemisia tabaci MED in China. Journal of Integrated Agriculture, 17(1), 158-163. https:// doi.org/10.1016/S2095-3119(16)61613-1

Wartig, L., Kheyr-pour, A., Noris, E., Kouchkovsky, F. D., Jouanneau, F., Gronenborn, B., \& Jupin,
I. (1997). Genetic analysis of the monopartite tomato yellow leaf curl geminivirus: Roles of V1, $\mathrm{V} 2$ and $\mathrm{C} 2 \mathrm{ORFs}$ in viral pathogenesis. Virology, 228(2), 132-140. https://doi.org/10.1006/ viro.1996.8406

Widarta, H., Hartono, S., Sulandari, S., Hertanto, C., \& Anastasia, E. (2017). Pengendalian terpadu penyakit kerupuk pada tanaman tembakau di Klaten, Jawa Tengah [Integrated leafcurl disease control on tobacco plants in Klaten, Central Java]. Jurnal Perlindungan Tanaman Indonesia, 21(1), 10-15. https://doi.org/10.22146/jpti.19363

Zubair, M., Zaidi, S. S, Shakir, S., Amin, I., \& Mansoor, S. (2017). An insight into Cotton leaf curl Multan betasatellite, the most important component of cotton leaf curl disease complex. Viruses, 9(10), 280. https://doi.org/10.3390/ v9100280 
